This item was submitted to Loughborough's Research Repository by the author.

Items in Figshare are protected by copyright, with all rights reserved, unless otherwise indicated.

\title{
Renewable energy powered desalination in Baja California Sur, Mexico
}

PLEASE CITE THE PUBLISHED VERSION

PUBLISHER

(C) Elsevier

VERSION

AM (Accepted Manuscript)

LICENCE

CC BY-NC-ND 4.0

REPOSITORY RECORD

Bermudez-Contreras, Alfredo S., Murray Thomson, and David Infield. 2019. "Renewable Energy Powered Desalination in Baja California Sur, Mexico". figshare. https://hdl.handle.net/2134/5964. 
This item was submitted to Loughborough's Institutional Repository (https://dspace.lboro.ac.uk/) by the author and is made available under the following Creative Commons Licence conditions.

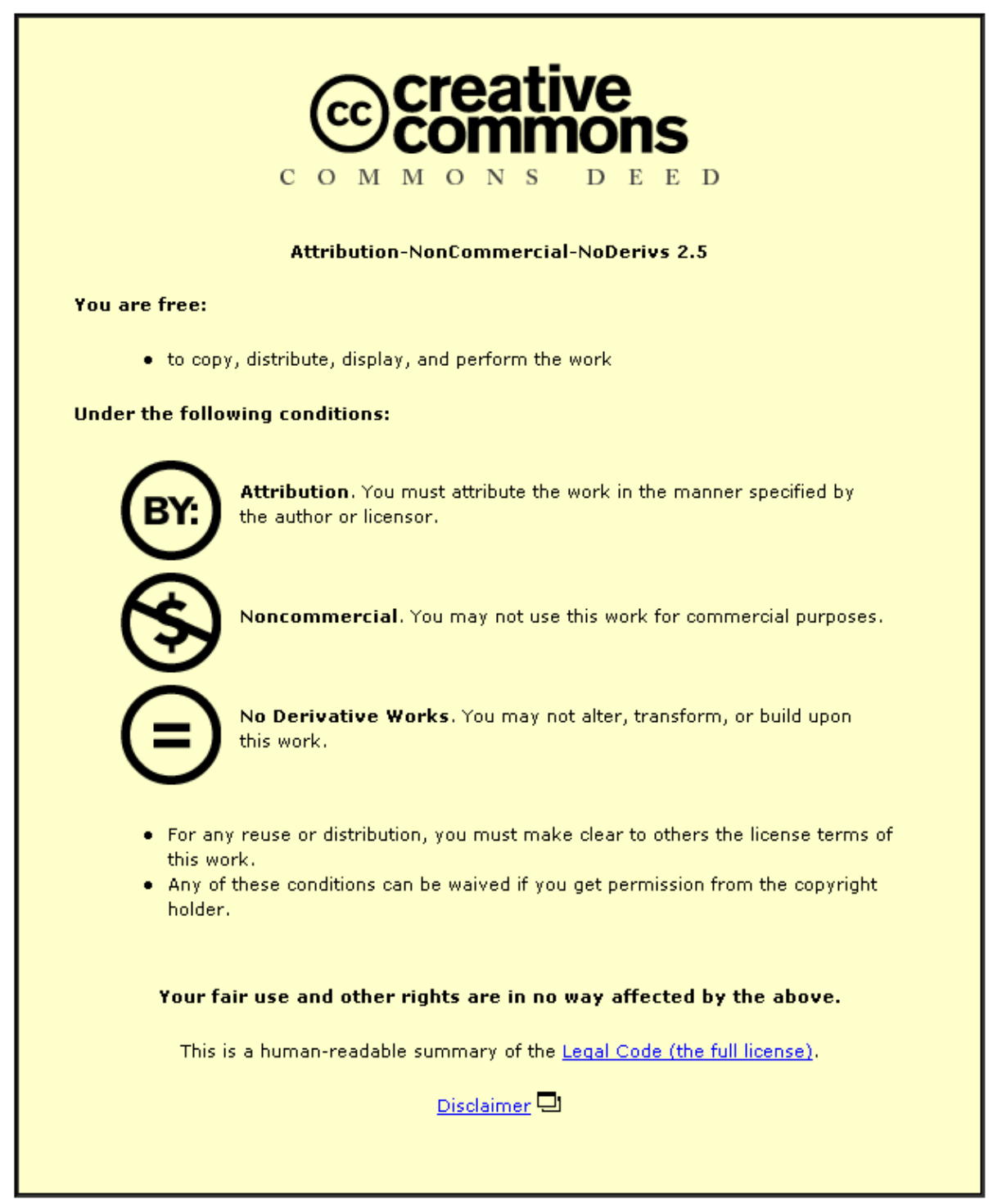

For the full text of this licence, please go to: http://creativecommons.org/licenses/by-nc-nd/2.5/ 


\title{
Renewable energy powered desalination in Baja California Sur, Mexico
}

\author{
Alfredo Bermudez-Contreras ${ }^{*}$, Murray Thomson and David G. Infield \\ CREST (Centre for Renewable Energy Systems Technology), Loughborough University, LE11 3TU, UK \\ Tel.+44 (1509) 228140; email: A.S.Bermudez-Contreras@lboro.ac.uk
}

\begin{abstract}
Baja California Sur (BCS) is an arid sparsely populated coastal state in northwest Mexico. Population growth, agriculture and booming tourism have lead to severe overexploitation of underground aquifers and saline intrusion. This paper reviews the current water and energy situation in BCS. The state enjoys very high levels of solar radiation, typically above $5 \mathrm{kWh} / \mathrm{m}^{2} / \mathrm{d}$, and the suitability of renewable energy powered desalination for BCS is discussed, including past efforts in BCS and present challenges for this technology.
\end{abstract}

Keywords: Photovoltaic; PV; Reverse osmosis; RO; Mexico

\section{Overview of Baja California Sur, Mexico}

Baja California Sur (BCS) is a state in northwest Mexico (Figure 1). With just over half a million inhabitants, BCS is the least populated state in Mexico and has the lowest population density (6.9 inhabitants $\left./ \mathrm{km}^{2}\right)$; it has the largest coastline $(2131 \mathrm{~km})$ and receives the least rainfall (174 mm a year) in the country. Population is spread over more than 2,400 settlements of various sizes; only 17 of them are urban (i.e. 2500 or more inhabitants). Rural population accounts for just over 78,000 people, $15 \%$ of the state's total $[1,2]$.

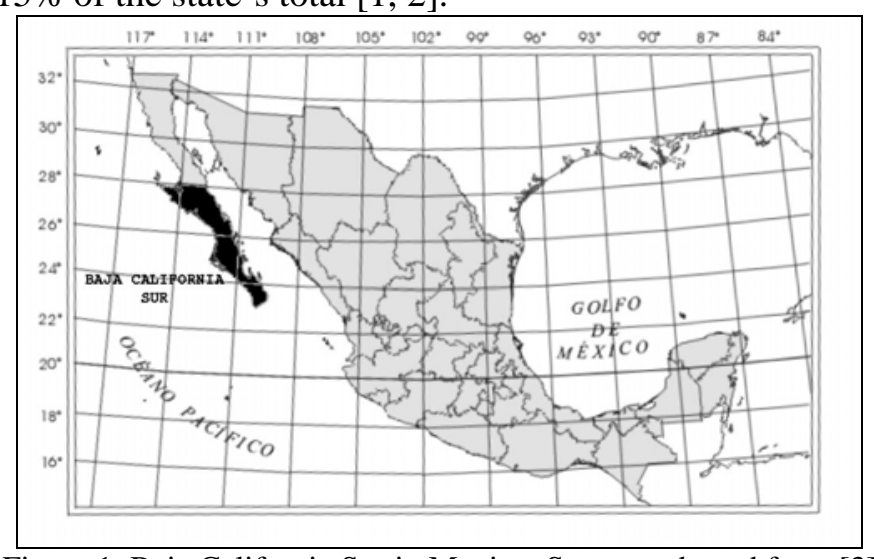

Figure 1. Baja California Sur in Mexico. Source: adapted from [3]

Tourism is one of the main economic activities in BCS and is now expanding rapidly. This, together with population growth and unsustainable agricultural practices, creates large and increasing demands on limited natural resources, particularly water and energy.

\footnotetext{
* Corresponding author
} 


\section{Water in BCS}

Water scarcity is perhaps BCS' most acute problem. Water availability per capita in BCS is very low (1,070 $\mathrm{m}^{3} /$ year) [4, 5]; in La Paz (the state capital) and Los Cabos (major tourist region) freshwater shares per capita are classed as "extremely low", only 436 and $701 \mathrm{~m}^{3} /$ year, respectively. Estimates predict that BCS' freshwater supplies will only cope with increasing demand for up to 5 years in a business-as-usual scenario [5, 6].

In 2003 99\% of freshwater came from underground sources [7]. At present, the main aquifers supplying urban centres and agricultural regions are overexploited or with saline intrusion or both; there are also problems of salination of soils due to overexploitation of the aquifers.

BCS does not have a state-wide water network. Instead, there are only local water pipelines to carry water from wells where it is extracted to the main urban areas. Across the state over 70,000 people lack access to the main water networks [8].

\section{Energy in BCS}

Mexico has considerable oil and natural gas reserves, but these are in the southeast of the country, not in BCS. BCS' supplies of fuels (e.g. gasoline, diesel, LPG) arrive mainly by sea.

BCS is the only region of the country that is not connected to any other electricity network (national or international) and therefore relies on its own generation capacity. Most of the electricity is generated using fossil fuels in thermal plants (Table 1).

Table 1. Electricity generation in BCS. Source: [1]

\begin{tabular}{|r|c|c|c|}
\hline GENERATION TYPE & $\begin{array}{c}\text { NUMBER OF POWER } \\
\text { STATIONS } \\
\text { CAPACITY } \\
\text { (MW) }\end{array}$ & $\begin{array}{c}\text { ELECTRICITY } \\
\text { GENERATED } \\
\text { (GWh/year) }\end{array}$ \\
\hline TOTAL & $\mathbf{1 0}$ & $\mathbf{4 8 5 . 4}$ & $\mathbf{1 , 5 4 9 . 9}$ \\
\hline SHERMAL SOURCES & $\mathbf{8}$ & $\mathbf{4 7 4 . 8}$ & $\mathbf{1 , 5 1 2 . 5}$ \\
\hline Gas & 1 & 112.5 & 633.9 \\
\hline Internal combustion & 2 & 163.7 & 103.6 \\
\hline GTHER SOURCES & 5 & 198.6 & 775.0 \\
\hline Wind & $\mathbf{2}$ & $\mathbf{1 0 . 6}$ & $\mathbf{3 7 . 5}$ \\
\hline
\end{tabular}

The state electricity grid does not cover the whole of the state (Figure 2); in the northern half of BCS, small grids around power stations distribute electricity locally. Despite great efforts, there are still around 20,000 people who do not have access to electricity (Table 2). 


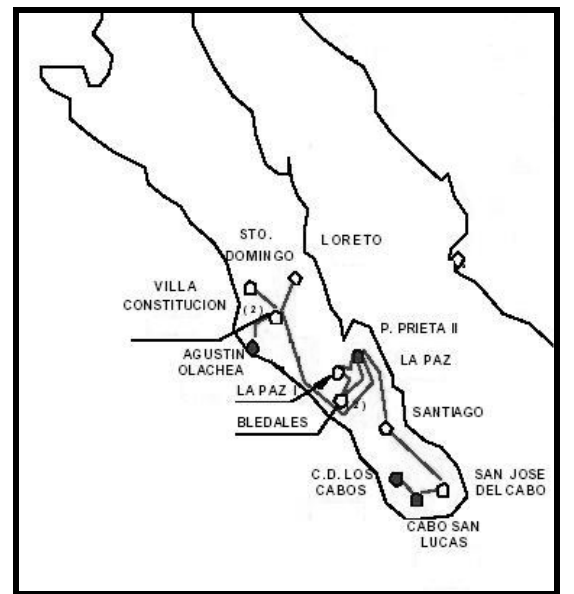

Figure 2. BCS’s electricity transmission grid. Source:[9]

Table 2. Access to electricity and water. Source: [8]

\begin{tabular}{|l|c|c|}
\hline & NUMBER & (\%) \\
\hline Population in homes & 483,686 & 100.00 \\
\hline Access to electricity & 463,679 & 95.86 \\
\hline Access to water network & 412,154 & 85.21 \\
\hline Electricity and water & 406,535 & 84.05 \\
\hline
\end{tabular}

\section{Renewable Energy in BCS}

\subsection{Solar}

One of the most abundant resources in BCS is solar radiation. Annual solar irradiance averages in BCS vary between 5 and $6 \mathrm{kWh} / \mathrm{m}^{2} /$ day, with lows of $3 \mathrm{kWh} / \mathrm{m}^{2} /$ day in winter and highs of 7 $\mathrm{kWh} / \mathrm{m}^{2} /$ day in summer $[10,11]$.

Solar energy is widely used across the whole peninsula in rural towns and fishing camps away from electricity networks. Applications such as water pumping systems and solar lighting can be found along the state. In a major effort, the Sandia National Laboratories in the USA managed the Mexico Renewable Energy Program, where in collaboration with other institutions from Mexico and the USA, installed 47 solar and solar-hybrid systems equating to over $140 \mathrm{~kW}$ of photovoltaic (PV) modules in BCS alone [12]. From these, the largest by far is in San Juanico which comprises $17 \mathrm{~kW}$ of PV modules, $70 \mathrm{~kW}$ of wind power, an $80 \mathrm{~kW}$ diesel generator and a battery bank [13].

\subsection{Wind}

In general, BCS is not a windy region, but estimates suggest that certain locations, mainly in the northwest, do have a good resource with average wind speeds ranging from 5 to $8 \mathrm{~m} / \mathrm{s}$ at $30 \mathrm{~m}$ above ground [14]. A recent study on wind power potential in the area [15] found average wind speeds between 2.6 and $6.2 \mathrm{~m} / \mathrm{s}$ at $10 \mathrm{~m}$ above ground for 15 wind monitoring stations. WAsP studies suggest power densities of 200 to $400 \mathrm{~W} / \mathrm{m}^{2}$ at $10 \mathrm{~m}$ for the northwest coast of the state [16-18]. 
Installed wind turbines in BCS include two in Guerrero Negro (rated at 250 and $600 \mathrm{~kW}$ ) and the those in San Juanico (described above).

\subsection{Geothermal}

BCS has 4 geothermal zones, namely, Agua Caliente, Centavito, Santispac and Las Tres Virgenes (LTV). LTV, on the northeast side of the state, is located in a volcanic complex; geothermal fluids seem to be heated by magma chambers associated with the complex. The geothermal gradient in this field varies from $8{ }^{\circ} \mathrm{C} / 100 \mathrm{~m}$ between depths of $150-400 \mathrm{~m}$ and $12{ }^{\circ} \mathrm{C} / 100 \mathrm{~m}$ in the range of 300-1300 m. In 2001, LTV was developed into a geothermal field with 10 MWe of capacity with prospects of expansion up to 25 MWe [19, 20].

\section{Desalination in BCS}

The state's water scarcity has triggered the search for alternatives to traditional groundwater extractions to cover water demands of population and industry. In the private sector, particularly large tourist resorts, many have installed their own desalination systems, most of them using brackish sources. The state government has also played an important role in the installation of desalination systems to supply remote settlements with freshwater across BCS. Most of these systems operate on seawater.

A survey of desalination systems in BCS [21] found 67 systems in operation between private and state-managed systems (Table 3), their sizes ranging from 2 to $1998 \mathrm{~m}^{3} /$ day. Most systems operate reverse osmosis processes; there are also 4 multi-stage flash plants in operation. All plants found in this survey are conventionally powered.

Additionally, the survey found 13 more systems planned or under construction. From the latter, the most outstanding is the reverse osmosis seawater desalination plant under construction in Cabo San Lucas, which when finished will have a capacity of 17,280 $\mathrm{m}^{3} / \mathrm{day}$ [22].

Table 3. Desalination capacity in BCS by water source and ownership. Source: from data in [21]

\begin{tabular}{|c|c|c|c|c|c|c|}
\hline & \multicolumn{2}{|c|}{ WATER SOURCE } & \multicolumn{3}{c|}{ OWNERSHIP } \\
\cline { 2 - 7 } & $\begin{array}{c}\text { Brackish } \\
\text { water }\end{array}$ & Seawater & Total & $\begin{array}{c}\text { Private } \\
\text { sector }\end{array}$ & Municipal & Total \\
\hline $\begin{array}{c}\text { Number of } \\
\text { plants }\end{array}$ & 54 & 13 & 67 & 50 & 17 & 67 \\
\hline $\begin{array}{c}\text { Capacity } \\
\text { (m/day) }\end{array}$ & 15,835 & 1,136 & 16,971 & 15,731 & 1,240 & 16,971 \\
\hline
\end{tabular}

\section{Past solar desalination demonstrations in BCS}

Due to its high levels of insolation and severe water scarcity, BCS' has seen some trials of solar-powered desalination of various types, scales and budgets. The following describes 3 past experiences: Sonntlan, Puerto Chale and El Pardito (see Table 4). 
Table 4. Past efforts in solar desalination in BCS

\begin{tabular}{|c|c|c|}
\hline PROJECT & CAPACITY $\left(\mathrm{m}^{3} /\right.$ day $)$ & REMARKS \\
\hline SMSF La Paz & 10 & $\begin{array}{c}\text { Solar multi-stage flash } \\
\text { desalination plant }\end{array}$ \\
\hline Sonntlan Las Barrancas & $20+20+8$ & Integral solar system \\
\hline Puerto Chale & 1 & Solar stills \\
\hline El Pardito & 0.175 & Large-section solar stills \\
\hline
\end{tabular}

\subsection{La Paz and Las Barrancas - Sonntlan}

In a joint project between the Federal Republic of Germany and Mexico in the late 1970s, a solar multi-stage flash distillation plant was built in a desalination research facility in La Paz. The project was called SMSF. With a capacity of $10 \mathrm{~m}^{3} /$ day, the plant was commissioned in 1980 .

The plant consisted of 10 stages (8 heat recovery and 2 heat rejection) and had a $194 \mathrm{~m}^{2}$ solar flat plate collector field for daytime operation, 2 X $162 \mathrm{~m}^{2}$ flat plate collector fields to supply heat to the energy storage for night time operation. The plant was designed to operate continuously $24 \mathrm{~h}$ a day; the storage could keep the plant working for over $28 \mathrm{~h}$ in normal conditions. A further $160 \mathrm{~m}^{2}$ parabolic concentrating collector field (see Figure 3) was also included, collectors were mounted on high-precision two-axis tracking bases. The plant operated satisfactorily according to its design [23-27].

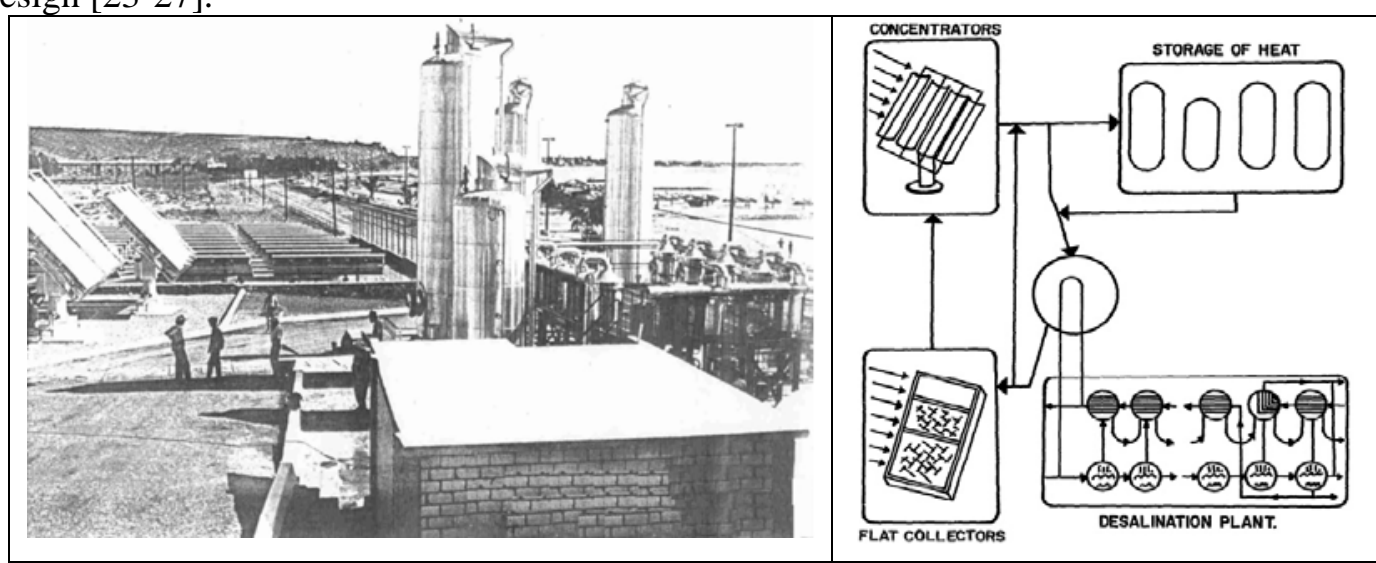

Figure 3. Left: photograph of the solar distillation plant in La Paz [24]. Right: schematic of the plant systems [25]

After the success of this project the German and Mexican governments signed agreements for more research collaboration which gave rise to Sonntlan, a larger solar energy research project in the early 1980s [24, 28]. Sonntlan had two parts, one in another state in Mexico researching air conditioning and hotwater systems for houses, and the one in Las Barrancas, BCS, which involved several different solar applications including solar desalination.

In Las Barranas, a fishing community on the coast of BCS, Sonntlan implemented an integral system providing drinking desalinated water, ice, hot water, communications, refrigeration and electricity to the community of 250 inhabitants [24, 28-33]. This included:

- A $250 \mathrm{~kW}$ peak PV generator

- A $1540 \mathrm{~m}^{2}$ solar hot water collector field (heat pipe collectors)

- 3 X $38 \mathrm{~m}^{3}$ hot water storage tanks 
- $550.8 \mathrm{~m}^{2}$ of parabolic trough concentrating collectors for the hot oil system

- A $16 \mathrm{~m}^{3}$ hot oil storage tank

- Heat exchanger between hot oil and hot water circuits

- Diesel generators

- An $8 \mathrm{~m}^{3} /$ day single stage waste heat recovery flash distillation unit

- A $20 \mathrm{~m}^{3} /$ day multiple stage solar flash distillation unit

- A $20 \mathrm{~m}^{3} /$ day reverse osmosis desalination unit

- An ice-making facility

- An absorption-compression deep freezing facility for local produce (fish)

- A PV-powered communications system

When the agreements ended, both plants (La Paz and Las Barrancas) operated for some time and then the projects were just abandoned. Although the reasons for this are not perfectly clear, the political climate of the time, the use of largely foreign technology and the lack local consultation can explain partly why these operations came to a stop.

\subsection{Puerto Chale - solar stills}

Prior to the Sonntlan projects, conventionally-powered desalination research and trials were already underway in BCS by CAAS, Mexico's saline waters commission. During the 1970s, CAAS also had in place solar stills fields in Puerto Chale and Punta Eugenia (Figure 4), small fishing villages with less than 150 inhabitants on the coast of BCS, producing 1 and $1.5 \mathrm{~m}^{3} /$ day of distilled water, respectively [34, 35].

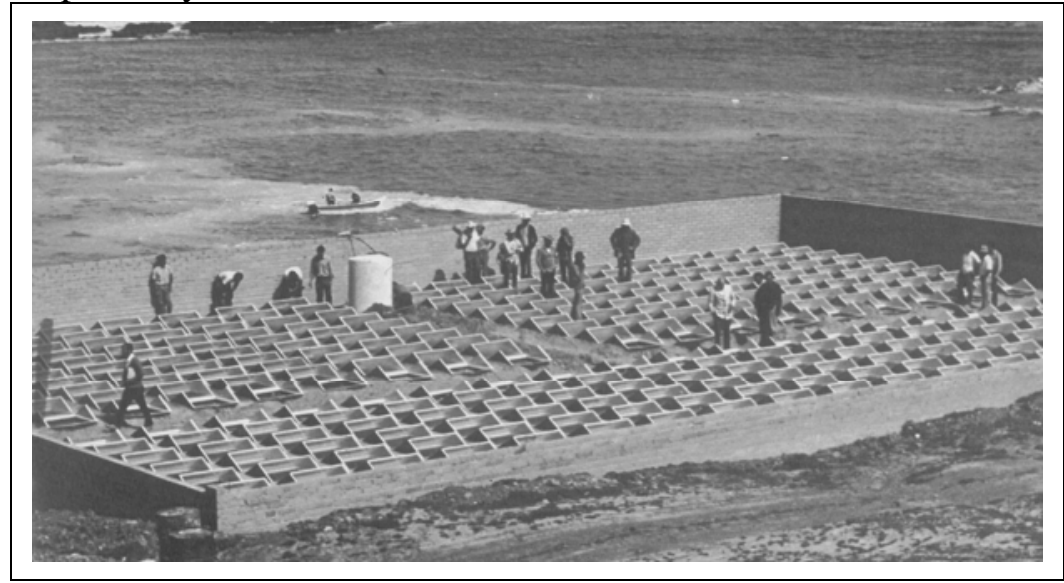

Figure 4. Solar stills in Punta Eugenia. Source: [34]

Later on, local research centre CIBNOR researched and tested so-called "canal solar stills" in the late 1980s. These consisted of a canal made up of ferrocemento ${ }^{2}$ sections joined with mortar and glass panels with a slope of around $30^{\circ}$ (Figure 5). A first prototype of $40 \mathrm{X} 1.5 \mathrm{~m}$ was built (active surface of $54 \mathrm{~m}^{2}$ ) and tested with encouraging results in 1988. A wind pump supplied the still with seawater from a beach well. The device produced $200 \mathrm{~L}$ on a good summer day, equating to $3.7 \mathrm{~L} / \mathrm{m}^{2}$ [24].

\footnotetext{
${ }^{2}$ A lightweight construction material made of mortar reinforced with a steel mesh
} 
The design was then trialled again in Puerto Chale. Here, a desalination plant of 6 canals of a total area of $300 \mathrm{~m}^{2}$ was built (Figure 5), expecting to produce around $1 \mathrm{~m}^{3} /$ day of freshwater, enough to cover the drinking water needs of the town. The plant's best recorded performance was $1.6 \mathrm{~m}^{3} /$ day [24].

To insure daily operation of the plant, the product water was given to a local businessman who in turn sold the water to the rest of the villagers. After 6 months of successful operation, the new government did not have the resources to ensure operation of the plant and it was abandoned. The person in charge of the plant went back to his old business of bringing brackish water to the town from a spring well $30 \mathrm{~km}$ away [24]. The town now has a reverse osmosis plant producing $15 \mathrm{~m}^{3} /$ day from brackish water [21].

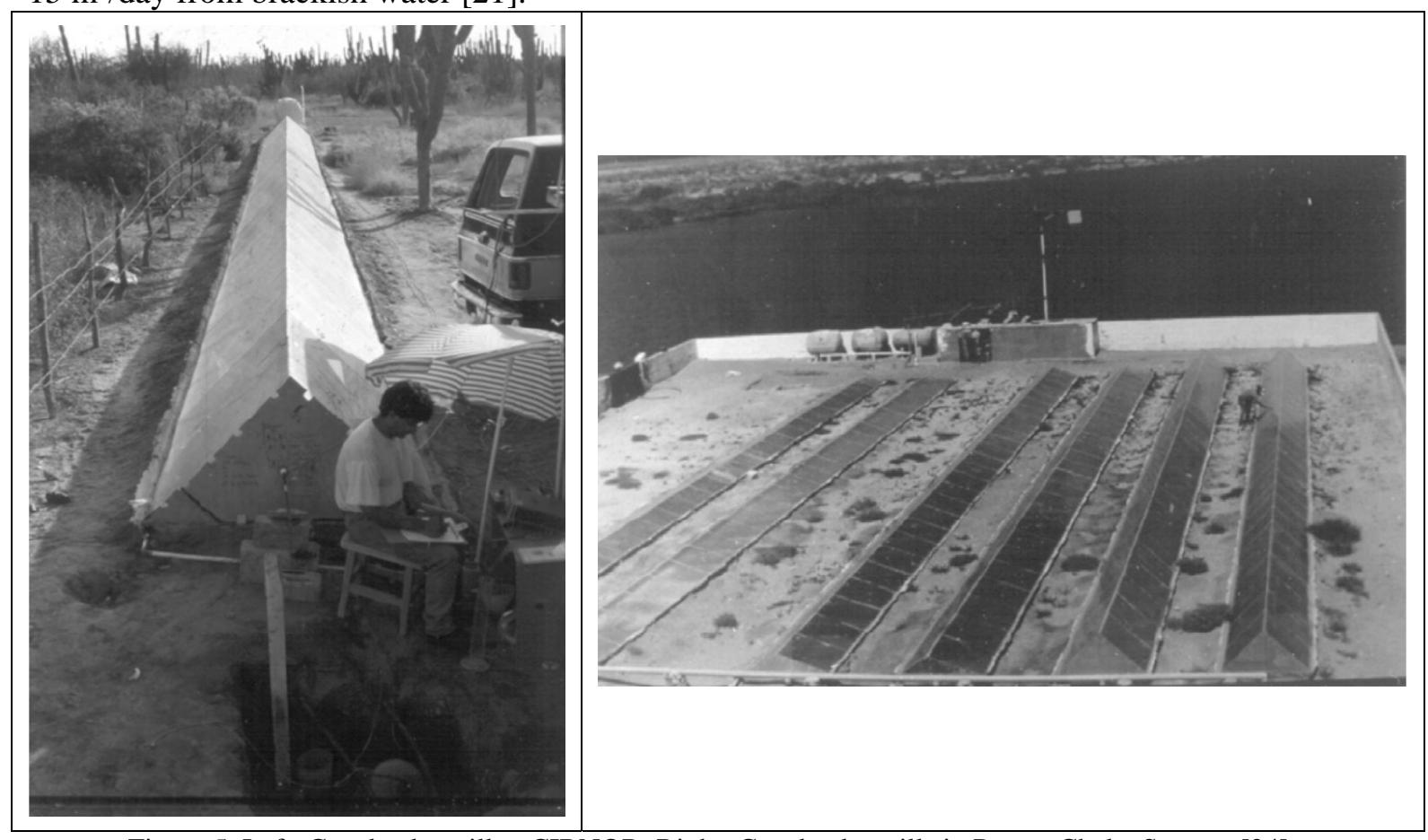

Figure 5. Left: Canal solar still at CIBNOR. Right: Canal solar stills in Puerto Chale. Source: [24]

\subsection{El Pardito - Large-section solar still}

Encouraged by the technical success of the canal solar stills in Puerto Chale, researchers at the state university, UABCS, designed and built another adaptation of the sloping roof solar still using materials similar to the canal solar stills. This device was called a large-section solar still (LSSS).

The dimensions of the prototype designed and tested at UABCS were $5 \mathrm{~m}$ wide, $10 \mathrm{~m}$ long and $2.5 \mathrm{~m}$ tall (Figure 6). On a good day, the prototype yielded up to $175 \mathrm{~L}$, which is $3.5 \mathrm{~L} / \mathrm{m}^{2}$ [24].

An LSSS of the same dimensions started operations for a small community in a small island in the Gulf of California known as El Pardito in 1993 [24]. 


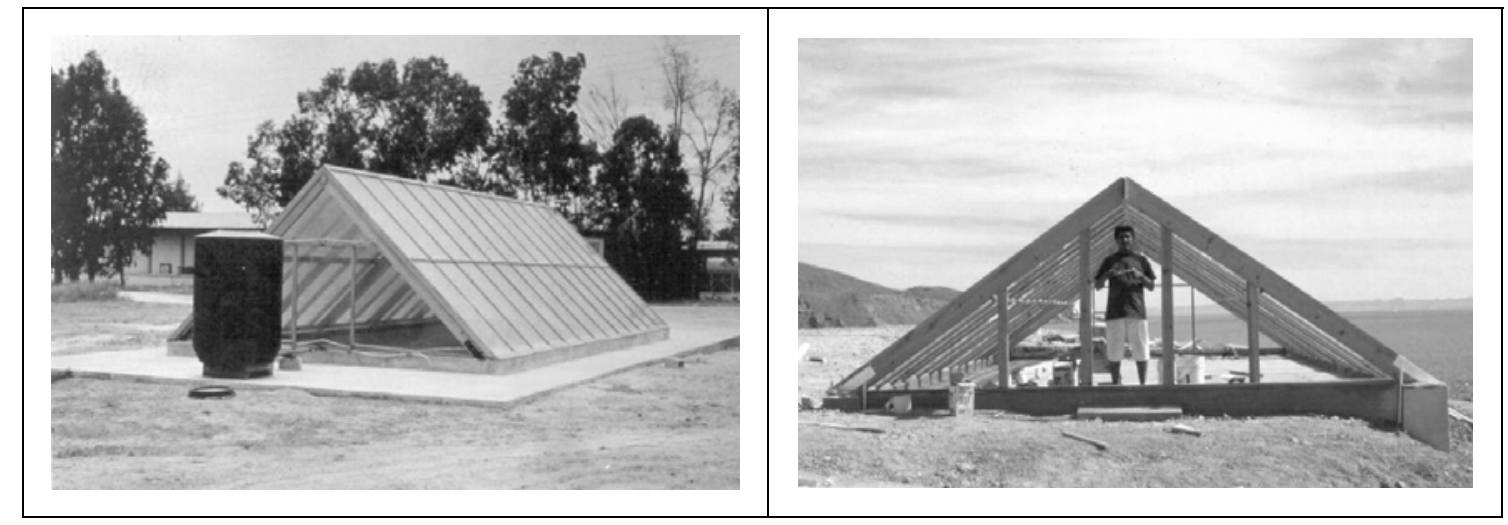

Figure 6. Left: LSSS at UABCS. Right: LSSS at El Pardito. Source: [24]

Other solar desalination efforts in BCS include a system researched at the local Technology Institute (ITLP) consisting of a solar still of stacked trays [24, 36] to produce distilled water for ITLP's laboratories and also the thorough research done by Miguel Angel Porta Gandara on solar stills [24].

\section{Current solar desalination in BCS}

The most successful solar desalination system currently operating in BCS is that developed by Mr Yan Kunczynski. This system uses a large solar photovoltaic (PV) array and battery bank to power seawater reverse osmosis (PVSWRO). The system can produce up to $19 \mathrm{~m}^{3} /$ day of freshwater with a total dissolved solids content of less than $250 \mathrm{ppm}$.

Recognising the importance of energy efficiency when using PV, Mr Kunczynski has tested various system configurations and brine stream energy recovery mechanisms including

- An ERI PX-15 pressure exchanger (now discontinued),

- Spectra Watermakers Clark pumps, and

- Danfoss axial piston motors.

He has achieved energy consumption as low as $2.6 \mathrm{kWh} / \mathrm{m}^{3}$ [37] and has accumulated over 70,000 hours of operation running entirely on solar energy [38].

\section{Discussion and conclusions}

Past and current solar desalination demonstrations in Baja California Sur follow a pattern found all over the world. The first efforts were primarily done in thermal desalination but advances in reverse osmosis membrane technology are now making the latter more successful, especially for applications with land space restrictions.

As there are no electricity or water networks covering the whole of BCS, it makes sense for small communities with no access to such networks but with brackish or seawater sources to have small systems generating electricity and producing freshwater exactly where they are required. Many such locations have also poor access to diesel and other fuels. The use of photovoltaics for electricity generation and brackish or seawater desalination is an attractive alternative for small systems in remote communities.

At the time of the Sonntlan project, thermal processes were more attractive as reverse osmosis membranes in this project required replacement every 3 months [39]. With today's advances in 
membrane technology, reverse osmosis desalination is economically viable and very competitive with other technologies. Nevertheless, despite photovoltaic seawater desalination by reverse osmosis (PVSWRO) being today technically viable, the economics limit its application. Energy recovery and energy storage are two issues in PVSWRO that significantly affect the performance and the economics of the application and which also require further work.

While large reverse osmosis desalination plants incorporate energy recovery systems, energy recovery is generally overlooked in small scale systems. Although small PVSWRO systems featuring energy recovery are more efficient, the main problem with small scale energy recovery devices is that there is no such device tailored for land-based applications producing up to $50 \mathrm{~m}^{3} /$ day. Rather, devices used in other fields have been adapted, scaled and researched in recent years. A successful energy recovery device would help reducing the energy requirements of PVSWRO systems and also the size of components and altogether improve the economic viability of the these systems and expand their application.

Another issue that remains unresolved is the suitability of using battery banks as energy storage in PVSWRO. Although some authors argue against them for causing trouble in their systems and requiring significant maintenance, others argue that they allow smooth operation of these systems and in some cases also continuous operation $24 \mathrm{~h}$. The ultimate effect of not including batteries is having the system cope with variable operation patterns of flow rates and pressure that follow instantaneous atmospheric conditions. Manufacturers of course object to such operation regimes. The underlying subject here is identifying what is less troublesome and more cost effective in remote locations lacking skilled personnel where PVSWRO systems normally find their application, replacing reverse osmosis membranes or replacing batteries.

Solving these two issues is crucial for the future success and wide-spread use of PVSWRO applications.

\section{References}

[1] INEGI, Anuario Estadistico. Baja California Sur. 2006, INEGI. Also available at: http://www.inegi.gob.mx/est/contenidos/espanol/sistemas/aee06/estatal/bcs/index.htm accessed (13/December/2006).

[2] Centro Estatal de Informacion, Indicadores Basicos - Baja California Sur. 2005, Gobierno del Estado de Baja California Sur: La Paz, B.C.S. Also available at: http://www.bcs.gob.mx/cei/centroestataldeinformacion/publicaciones/publicaciones.html accessed (13/December/2006).

[3] INEGI, Baja California Sur. 2000, INEGI. Also available at: http://mapserver.inegi.gob.mx/geografia/espanol/estados/bcs/bcs.pdf?c=459\&e=03\&CFID $=1261982 \&$ CFTOKEN=92846960 accessed (12/December/2006).

[4] Comision Nacional del Agua, Estadisticas del Agua en Mexico 2004. 2004, Comision Nacional del Agua: Mexico, D.F. Also available at: www.cna.gob.mx accessed (13/December/2006).

[5] Plan Estatal de Desarrollo 2005-2011, http://www.bcs.gob.mx/varios/plandesarrollo/, accessed (13/December/2006).

[6] M. Bertram, et al., Environmental Technology and Service Opportunities in the Baja California Peninsula. 2003, Institute for Regional Studies of the Californias - San Diego 
State University. Also available at: http://www.swrcb.ca.gov/border/docs/etsentire.pdf accessed (30/March/2006).

[7] INEGI, Captacion, Tratamiento y Suministro de Agua - Censos Economicos 2004. 2005, INEGI. Also available at: http://www.inegi.gob.mx/est/contenidos/espanol/proyectos/censos/ce2004/tb_agua.asp accessed (13/December/2006).

[8] INEGI, II Conteo de Poblacion y Vivienda 2005. Tabulados basicos. Baja California Sur. 2006, INEGI. Also available at: http://www.inegi.gob.mx/est/contenidos/espanol/sistemas/conteo2005/default.asp?c=6790 accessed (13/December/2006).

[9] C.R. Carlon Velazquez, Red electrica,Personal communication, May/2003.

[10] I. Galindo Estrada and M. Valdés Barrón, Mexico: Atlas de Radiacion Solar. Documentos de analisis y prospectiva del Programa Universitario de Energia. 1991: PUE - UNAM.

[11] NREL, Annual Averaga Global Horizontal Solar Radiation for Mexico. 1998, NREL. Also available at: http://www.re.sandia.gov/en/ti/ti-fs.htm accessed (13/December/2006).

[12] Installed Systems on the Program's Pilot Phase, http://www.re.sandia.gov/en/ac/sy/syrt.htm, accessed (29/May/2006).

[13] D. Corbus, C. Newcomb, and Z. Yedall, San Juanico Hybrid Power System Technical and Institutional Assessment. 2004. NREL Preprint - To be presented at the World Renewable Energy Congress VIII, Denver, Colorado, August 29-September 3, 2004. Also available at: http://www.nrel.gov/docs/fy04osti/36270.pdf accessed (30/March/2006).

[14] NREL, Mexico - Northwest Baja California Sur Wind Resource Map. 2000, NREL. Also available at: http://www.re.sandia.gov/en/ti/ti-fs.htm accessed (13/December/2006).

[15] O.A. Jaramillo, R. Saldana, and U. Miranda, Wind power potential of Baja California Sur, Mexico. Renewable Energy, 2004. 29(13): p. 2087-2100.

[16] R. Saldaña and U. Miranda, Densidad de Potencia Media Anual (10 m) Punta Eugenia. 2001, IIE - Gerencia de Energias No Convencionales. Also available at: http://genc.iie.org.mx/genc/siger/frames.asp?mcontador=12577\&url=mapas1\%2Ehtm accessed (13/December/2006).

[17] R. Saldaña and U. Miranda, Densidad de Potencia Media Anual (10 m) Bahia Asuncion. 2001, IIE - Gerencia de Energias No Convencionales. Also available at: http://genc.iie.org.mx/genc/siger/frames.asp?mcontador=12577\&url=mapas1\%2Ehtm accessed (13/December/2006).

[18] R. Saldaña and U. Miranda, Densidad de Potencia Media Anual (10 m) La Laguna. 2001, IIE - Gerencia de Energias No Convencionales. Also available at: http://genc.iie.org.mx/genc/siger/frames.asp?mcontador=12577\&url=mapas1\%2Ehtm accessed (13/December/2006).

[19] E. Santoyo, et al. Thermal Evolution Study of the LV-3 Well in the Tres Virgenes Geothermal Field, Mexico. In World Geothermal Congress 2000. 2000. Kyushu - Tohoku, Japan.

[20] S.P. Verma, et al., Fluid chemistry and temperatures prior to exploitation at the Las Tres Virgenes geothermal field, Mexico. Geothermics, 2006. 35(2): p. 156-180.

[21] V.M. Juarez Cortez, Encuesta Sobre Plantas Desaladoras en Baja California Sur, SEMARNAT-BCS,Personal communication (E-mail), 04/December/2006. 
[22] Proyecto: Planta Desaladora de Agua de Mar para el Abastecimiento de Cabo San Lucas, B.C.S., http://oomsapaslc.gob.mx/, accessed (13/December/2006).

[23] S. Loupasis, Technical Analysis of Existing RES Desalination Schemes. 2002, Commission of the European Communities - Directorate General for Energy and Transport. Also available at: On-line available http://www.nad.gr/readsa/files/TechnodatabaseREDDES.PDF accessed (15/December/2006).

[24] J.L. Fernandez Zayas and N. Chargoy del Valle, Destilacion Solar de Agua de Mar en Mexico 1983-2003 (forthcoming).

[25] R. Manjarrez and M. Galvan, Solar multistage flash evaporation (SMSF) as a solar energy application on desalination processes. Description of one demonstration project. Desalination, 1979. 31(1-3): p. 545-554.

[26] DIGAASES, La Desalacion Solar en Mexico. 1979, Direccion General para el Aprovechamiento de Aguas Salinas y Energia Solar (DIGAASES).

[27] Dornier and DIGAASES, Solar Multi-Stage Flash Desalination Plant (SMSF) La Paz Baja California Sur Mexico.

[28] DIGAASES, Proyecto Sonntlan. Mexico-Republica Federal Alemana. Fase Rural. Las Barrancas, B.C.S. 1982, Direccion General de Aprovechamiento de Aguas Salinas y Energia Solar.

[29] R. Best and I. Pilatowsky, Solar assisted cooling with sorption systems: status of the research in Mexico and Latin America. International Journal of Refrigeration, 1998. 21(2): p. 100-115.

[30] F. Marquez, et al. Renewable Energy in Mexico: Experiences, Actions and Perspectives. In 2000-2001 APEC Energy R\&D and Technology Transfer Seminar "Fostering the Commercially Viable Deployment of New and Renewable Energy Technologies for Rural Development". 2000. Morelos, Mexico.

[31] E.A. Rincon Mejia, Estado del Arte de la Investigacion en Energia Solar en Mexico. Edicion especial ed. Cuadernos FICA. 1999, Mexico, D.F.: Fundacion ICA.

[32] Dornier and DIGAASES, Sonntlan. Presentation. Project Phase 2. Las Barrancas/Mexicali. 1980, Dornier.

[33] Dornier and DIGAASES, Sonntlan. Final Presentation. Project Phase 1. La Paz/Mexicali. 1979, Dornier.

[34] Comision para el Aprovechamiento de Aguas Salinas, Informe - Dos Anos de Labores 1971-1973. 1973, Comision para el Aprovechamiento de Aguas Salinas.

[35] Comision para el Aprovechamiento de Aguas Salinas, 4 Anos de Labores 1971-1975. 1975, Comision para el Aprovechamiento de Aguas Salinas.

[36] J. Fernandez and N. Chargoy, Multi-stage, indirectly heated solar still. Solar Energy, 1990. 44(4): p. 215-223.

[37] Y. Kunczynksi. Development and Optimization of 1000-5000 GPD Solar Power SWRO. In IDA World Congress on Desalination and Water Reuse. 2003. Bahamas.

[38] MEDRC, OPT Uses Grant to Lower Energy Consumption of SWRO Systems, in The Newsletter of The Middle East Desalination Research Center. 2006. p. 8.

[39] E. Obermayr,Personal communication, June/2006. 